\title{
AKTUALISASI KOMPETENSI PEDAGOGIS GURU PROFESIONAL DALAM MENINGKATKAN MOTIVASI BELAJAR SISWA
}

\author{
Yohana $^{25}$ \\ Surel: yohana.nova@yahoo.com
}

\begin{abstract}
Abstrak
Kompetensi pedagogik merupakan kemampuan yang harus dimiliki guru. Penelitian ini bertujuan untuk kompetensi guru dalam perencanaan pembelajaran, proses pembelajaran, dan dapat meningkatkan motivasi belajar siswa. Kompetensi pedagogis ini meliputi pemahaman peserta didik, guru dalam perencanaan pembelajaran, memahami dasar-dasar pendidikan untuk keberlangsungan pembelajaran, merancang dan melaksanakan evaluasi pembelajaran, serta mengajak peserta didik agar dapat menuangkan potensi yang dimiliki oleh peserta didik. Komponen-komponen ini adalah bagian yang tidak dapat dipisahkan akan tetapi komponen ini merupakan kesatuan dari pembentukan guru professional. Penelitian ini dilakukan dengan menggunakan pendekatan kualitatif.
\end{abstract}

Kata Kunci: Kompetensi Pedagogis, Motivasi Belajar, Profesionalisme Guru

\section{PENDAHULUAN}

Pendidikan sekarang ini dituntut untuk dapat mempersiapkan peserta didik mampu menghadapi perkembangan-perkembangan pada saat iniyang begitu cepat. Bukan hanya peserta didik sebagai pendidik juga harus mampu menghadapi perkembangan yang ada dilingkungannya yang dimana memang merupakan kemampuan profesional yang harus dimiliki dalam bidang masing-masing untuk menanggapi perkembangan yang ada.Sebagai pendidik yg professional harus dapat memberikan dan menjadi motivasi peserta didik dalam menghadapi perkembangan. Dalam rangka mendukung profesionalisme guru sebagaimana diharapkan, maka setiap guru memiliki sekuranganya empat kompetensi dasar, yaitu kompetensi pedagogis, kompetensi kepribadian, kompetensi sosial dan kompetensi profesional. Meskipun ada pemilihan keempat kompetensi tersebut, namun dalam implementasinya merupakan satu kesatuan yang saling terkait. Menurut Usman (1995) bahwa karakteristik guru professional diantaranya memiliki kompetensi pendidikan, menunaikan peranannya, memiliki keperibadian yang luhur, membantu peserta didik dalam menimbulkan sikap positif, memahami hambatan pendidikan.Sudjana (2011:19-20) menyatakan bahwa pada dasarnya kompetensi guru bertugas sebagai pengajar, pembimbing, maupun sebagai administrator kelas. Sebab itu pemahaman secara menyeluruh terhadap muatan dari kompetensi-kompetensi ini menjadi keharusan. Tulisan ini menyajikan satu di antara kompetensi tersebut tidak berarti memisahkannya dari satu kesatuan dengan komptensi-kompetensi lainnya.

${ }^{25}$ Program Pascasarjana Universitas Negeri Medan 
Selain profesionalisme guru, sisi kompetensi merupakan komponen utama yang harus dimiliki dan menjadi penentu keberhasilan sistem pembelajaran yang akan dilakukan nantinya. Artinya guru berupaya untuk cakap dan mampu melaksanakan kewajiab sebagai tenaga pendidik dan juga mampu mempertanggung-jawabkannya. Hamalik (2012:57), menyatakan bahwa pembelajaran merupakan kombinasi yang tersusun meliputi unsur-unsur manusiawi, material, fasilitas, perlengkapan, dan prosedur yang saling mempengaruhi mencapai tujuan pembelajaran.

Hamalik (Djamarah, 2011:148), menyebutkan bahwa motivasi adalah suatu perubahan energi di dalam pribadi seseorang yang ditandai dengan timbulknya afektif (perasaan) dan reaksi untuk mencapai tujuan. Perubahan energi dalam diri seseorang itu berbentuk aktivitas nyata berupa kegiatan fisik, karena seseorang memiliki tujuan tertentu dari aktivitasnya, maka seseorang memiliki motivasi yang kuat untuk mencapainya dengan segala upaya yang dapat dia lakukan untuk mencapainya.

Uno (2008:3) menjelaskan bahwa motivasi berasal dari kata motif yang dapat diartikan sebagai kekuatan yang terdapat dalam diri individu, yang menyebabkan individu tersebut bertindak atau berbuat. Motif tidak dapat diamati secara langsung, tetapi dapat diinterpretasikan dalam tingkah lakunya, berupa rangsangan, dorongan, atau pembangkit tenaga munculnya suatu tingkah laku tertentu. Motivasi dan peran guru sebagai pendidik merupakan peran dan fungsi yang berkaitan dengan tugas-tugas dalam memberi bantuan dan dorongan.

Kompetensi Pedagogik merupakan salah satu jenis kompetensi yang mutlak perlu dikuasai guru. Kompetensi Pedagogik pada dasarnya adalah kemampuan guru dalam mengelola pembelajaran peserta didik. Kompetensi Pedagogik merupakan kompetensi khas, yang akan membedakan guru dengan profesi lainnya dan akan menentukan tingkat keberhasilan proses dan hasil pembelajaran peserta didiknya. Kompetensi pedagogiksebagai kemampuan yang harus dimiliki guru.

Pedagogik secara etimologi berasal dari bahasa Yunani yaitu 'paid 'berarti "anak" dan 'agogus' berarti "membimbing. Oleh karena itu pedagogi sering diartikan sebagai ilmu dan seni untuk mengajarkan anak-anak (Depdiknas, 2006: 7). Kompetensi yang harus dimiliki oleh guru ada empat kompetensi, yakni kompetensi pedagogik, kepribadian, sosial serta kompetensi profesional (Pasal 10 ayat (1) UU No. 14 tahun 2005 tentang Guru dan Dosen). Kemampuan ini berupa kemampuan melakukan rancangan pembelajaran yang selaras pelajaran yang diajarkan oleh pendidik selanjutnya pendidik dituntut pula mampu melakukan tindakan nyata di kelas dalam memberikan informasi secara empatik, santun dan efektif. Kompetensi pedagogik adalah kemampuan mengelola pembelajaran peserta didik. Kompetensi lainnya yakni kompetensi kepribadian, yang merupakan kemampuan pribadi yang mantap, berakhlak mulia, arif dan berwibawa serta menjadi teladan peserta didik (Ni'am, 2006). Menurut Gordin 
sebagaimana yang dikutip oleh Mulyasa, bahwa ada enam aspek atau ranah yang terkandung dalam konsep kompetensi, yaitu sebagai berikut (Mulyasa, 2007), yakni pengetahuan, pemahaman, kemampuan, nilai, sikap dan minat.

Pemahaman peserta didik merupakan faktor yang sangat penting dalam pelaksanaan pendidikan dan pembelajaran. Jika guru memahami peserta didik dengan baik, maka ia dapat memilih dan menentukan sumber-sumber belajar yang tepat, pendekatan-pendekatan yang sesuai, mampu mengatasi masalah-masalah pembelajaran sehari-hari dengan baik.

\section{METODE PENELITIAN}

Dalam mengkaji aktualisasi kompetensi pedagogik dilakukan penelitian terhadap Sekolah Dasar Negeri 060068 Medan. Pengambilan sample dilakukan secara clustersampling. Metode pengumpulan data dengan kuesioner dan instrumennya berupa angket tertutup dan terbuka. Penelitian ini menggunakan jenis penelitian kualitatif deskriptif.

\section{HASIL PENELITIAN DAN PEMBAHASAN}

Coding Data pada Kompetensi Pedagogik yang dimiliki Guru SD hasil penelitian berdasarkan analisa coding data yang dilakukan, dibagi menjadi tiga bagian yang berurutan dimulai dari open coding, axial coding dan selective coding pada kompetensi pedagogik yang dimiliki guru. Open Coding Berikut ini adalah bagian dari open coding yang dibuat berdasarkan topik penelitian yang dilakukan:

Kategori penguasaan karakteristik peserta didik, dengan konsep sebagai berikut :

Pemahaman karakteristik peserta didik terdiri atas beberapa kegiatan, yakni: 1) Fisik melalui pendekatan keolahragaan. 2) Intelektual \& Sosial melalui Pendekatan Keilmuan. 3) Emosional-Moral-Spritual melalui pendekatan sopan santun serta keagamaan.

Identifikasi potensi peserta didik melalui beberapa langkah, yakni: 1)

Evaluasi 2) Latihan Soal

Identifikasi kemampuan awal peserta didik, melalui beberapa kegiatan sekolah berupa : 1) Perkenalan diri peserta didik 2) Wawancara tentang keluarga, diri secara jasmani, serta kemampuan berhitung. d. Identifikasi kesulitan belajar peserta didik melalui test awal yang ringan.

Kategori penguasaan teori belajar, dengan konsep sebagai berikut : a. Menggunakan teori belajar kelompok. b. Pembelajaran berorientasi pada karakteristik peserta didik. c. Menggunakan pendekatan tematis pada kelas awal.

Kategori pengembangan kurikulum, dengan konsep sebagai berikut :

Penentuan tujuan lima mata pelajaran SD/MI berdasarkan standar isi kurikulum yang berlaku.

Evaluasi hasil belajar sebagai acuan pengalaman belajar peserta didik. 
Penggunaan metode Tematik 2006 dan KTSP.

Pengembangan instrumen penilaian di kegiatan belajar mengajar.

Kategori Penyelenggaraan pembelajaran yang mendidik, dengan konsep sebagai berikut :

Guru memberikan keleluasan berimajinasi.

Guru melakukan pemetaan kondisi lingkungan.

Pembelajaran fokus berpijak pada kurikulum 2006 secara kaku.

Guru mengarahkan untuk melakukan pembelajaran di Laboratorium.

Berinteraksi dengan peserta didik secara transaksional melalui sesi tanya jawab guna mengukur tingkat pemahaman peserta didik. 5. Kategori pemanfaatan teknologi informasi dan komunikasi juga digunakan dalam pembelajaran, namun masih kurang dioptimalkan. 6. Kategori memfasilitasi pengembangan potensi peserta didik, dengan konsep sebagai berikut : a. Adanya kegiatan exstra kurikuler di sekolah. b. Kebebasan memilih exstra kurikuler di sekolah. c. Kegiataan exstra kurikuler fokus pada prikomotorik peserta didik. 7. Kategori kemampuan berkomunikasi, dengan konsep sebagai berikut : a. Guru menggunakan pendekatan 'salam'. b. Melakukan penjelasan setiap materi secara tepat dan berguna. c. Adanya tes awal pada ranah psikologi peserta didik. d. Melakukan kegiatan mendidikan seperti test pidato dan menyanyi. 8. Kategori kemampuan melakukan penilaian dan evaluasi, dengan konsep sebagai berikut : a. Penilaian berpijak pada raport peserta didik. b. Aspek penilaian berupa hasil dan pengaruh kegiatan pembalajaran. c. Tiga konsep pengembangan dalam penilaian berupa aspek afektif, kognitif dan psikomotorik peserta didik

Axial Coding Merupakan prosedur yang diarahkan untuk melihat apakah terdapat keterkaitan antara kategorikategori yang dihasilkan melalui open coding di atas, yakni sebagai berikut:

Fenomena, merupakan fenomena utama yang menjadi fokus penelitian. Fenomena utama dalam penelitian ini adalah kompetensi pedagogik yang dimiliki guru SD.

Kondisi kausalitas, merupakan kondisi yang menjadi penyebab. Kondisi kausalitas yang terjadi adalah kemampuan guru dalam melakukan kegiatan belajar mengajar yakni dengan mampu mengembangkan indikator kompetensi pedagogik sejalan dengan arahan dari Permendiknas No. 16 Tahun 2007. Seperti kemampuan melakukan pemahaman terhadap karakteristik peserta didik dari aspek fisik, moral, emosional dan sebagainya.

Konteks mengacu pada hal-hal yang melingkari terjadinya suatu fenomena. Ada beberapa konteks dapat dikatakan guru SD memiliki kompetensi pedagogik yang sejalan dengan Permendiknas No. 16 Tahun 2007 dan memiliki kemampuan untuk mengembangkannya yakni sebagai 
berikut:

Adanya pendekatan yang mampu memahami karakteristik peserta didik.

Adanya pemahaman teori belajar yang baik dimiliki oleh guru

Penggunaan metode pembelajaran yang tepat guna, yakni digunakan metode tematik bagi murid SD.

Adanya pengembangan materi yang sejalan dengan kurikulum 2006.

Tingkat pemahaman terhadap teknologi pembelajaran masih kurang menjadi kendala yang harus dibenahi.

Pemberian ekstrakurikuler bagi peserta didik sebagai wadah pengembangan potensi diri.

Penggunaan pendekatan "salam" antara guru dan murid sebagai bahasa komunikasi yang empatik dan santun.

Adanya evaluasi melalui raport semester maupun laporan mingguan.

Hasil evaluasi akan dilakukan remedian dan pengayaan.

Adanya upaya perbaikan kualitas guru.

Menerapkan PTK bagi masing-masing guru.

Konsekuensi pengaruh. Konsekuensi yang terjadi bahwa kemampuan pemahaman peserta didik meningkat dengan adanya pembelajaran yang mendidik serta ditambahkan adanya remedial bagi yang kurang mampu dalam pembelajaran.

Strategi interaksi sebagai wujud tindakan. Ada beberapa langkah aktif yang dilakukan guru SD yakni:

penyiapan guru yang sesuai dan kompeten dengan materi pembelajaran; penggunaan metode tematik bagi peserta didik;

penyesuaian antara pembelajaran di kelas dengan kurikulum yang

berlaku;

pemberian praktek mata pelajaran tertentu;

pemberian ekstrakurikuler bagi peserta didik;

pemberian test psikologi di awal semester;

adanya evaluasi terhadap sisi afektif, kognitif dan psikomotorik peserta didik;

adanya laporan mingguan dan semester sebagai evaluasi peserta didik; adanya pertemuan guru dan murid;

adanya jam tambahan sebagai remedial;

k)peningkatan kualitas guru melalui musyawarah, diskusi dan penelitian tindakan kelas.

Selective Coding Kompetensi pedagogik yang dimiliki didukung oleh pemahaman yang bagus serta penerapan tepat guna dalam pembelajaran, sehingga membuat peserta didik nyaman dan sangat menikmati sesi pembelajaran. Selain itu, kompetensi pedagogik guru SD ini digambarkan melalui upaya pemahaman terhadap karakteristik peserta didik dan tingkat kemampuan peserta didik sejak awal sudah dapat diketahui dan dikenal dengan baik. Pada akhirnya akan 
mempermudah jalannya pembelajaran. Namun dalam tahap pembelajaran diperlukan pula evaluasi dan penilaian sebagai tolak ukur keberhasilan sebuah pembelajaran.

\section{SIMPULAN}

Kompetensi pedagogik yang dimiliki Guru SD Negeri 060068 Medan sudah sejalan dengan Peraturan Menteri Pendidikan Nasional Nomor 16 Tahun 2007, namun perlu ada beberapa perbaikan/ peningkatan sehingga dapat menjadikan guru yang berkualitas serta memiliki kompetensi yang sejalan dengan standar kompetensi yang ditetapkan oleh Pemerintah. Profesionalisme guru berakar dari kemampuanmengaktualisasikan empat kompetensi, yaitu kompetensi pedagogis,kompetensi kepribadian, kompetensi sosial dan kompetensi profesional.

\section{DAFTAR RUJUKAN}

Depdiknas, Direktorat Peningkatan Mutu Pendidik dan Tenaga

Kependidikan Nonformal. (2006). Pengembangan

Kompetensi Pedagogis dan Andragogi Tutor Pendidikan

Kesetaraan. Jakarta: Direktorat PTK-PNF.

Djamarah, S. B., 2011. Psikologi Belajar. Jakarta: Rineka

Cipta. Hamalik, O., 2012. Kurikulum dan Pembelajaran.

Jakarta: Bumi Aksara.

Mulyasa, E. (2007). Standar Kompetensi dan Sertifikasi Guru. Bandung: Remaja Rosdakarya.

Ni’am, A (2006). Membangun Profesionalitas Guru. Cet Ke 1.

Jakarta: ELSAS. Sudjana, N., 2011. Dasar-Dasar Proses Belajar

Mengajar. Bandung: Sinar Baru

Algesindo.

Usman U. (1995). Menjadi Guru Profesional. Bandung: Remaja Rosda Karya. 